\title{
Церковь и общество: место и значение православных песнопений в современном социуме
}

\author{
Владимир Лебецкий \\ Chrześcijańska Akademia Teologiczna w Warszawie \\ Polska \\ ORCID: 0000-0003-4009-9407 \\ lebiecki.music@gmail.com
}

\begin{abstract}
W. Lebiecki, Church and society: the place and significance of Orthodox chants in modern society, Elpis, 21 2019: 9-13.
W. Lebiecki, Kościót i społeczeństwo: miejsce i znaczenie śpiewów prawosławnych we wspótczesnym społeczeństwie, Elpis, 212019 : 9-13.
\end{abstract}

\begin{abstract}
The article raises questions of the importance of Orthodox chants in the life of modern society, considers the relevance of their performance on the concert stage, outside the liturgical practice, and analyzes the liturgical repertoire and the dominant factors necessary for the composer, who begins to create Orthodox works. At the same time, the Festivals of Orthodox chants, their spheres of influence on listeners and society are systematized and compared.
\end{abstract}

\begin{abstract}
Streszczenie: Artykuł porusza pytania o znaczenie śpiewów prawosławnych w życiu współczesnego społeczeństwa, rozważa znaczenie ich występów na scenie koncertowej, poza praktyką liturgiczną, i analizuje repertuar liturgiczny oraz dominujące czynniki konieczne dla kompozytora, który zaczyna tworzyć dzieła prawosławne. W tym samym czasie festiwale śpiewów prawosławnych, ich sfery wpływów na słuchaczy i społeczeństwo są usystematyzowane i porównywane.

Аннотация: В статье поднимаются вопросы значимости православных песнопений в жизни современного общества, рассматривается актуальность их исполнения на концертной эстраде, вне богослужебной практики, а также анализируется богослужебный репертуар и доминирующие факторы, необходимые композитору, приступающему к созданию церковных и духовных сочинений. Одновременно систематизируются и сопоставляются фестивали православных песнопений, их сферы воздействия на слушателей и социум.
\end{abstract}

Keywords: Orthodox Church, society, orthodox church singing

Słowa kluczowe: Cerkiew prawosławna, społeczeństwo, prawosławny śpiew cerkiewny

Ключевые слова: Церковь, общество, православные песнопения

Современные концертные афиши очень часто информируют нас о предстоящем концерте песнопений православной церкви, порой это связано непосредственно с церковными праздниками или иными событиями. Иногда такие мероприятия происходят под лозунгом вечеров духовной или иерковной музыки. А организация и проведение фестивалей православных песнопений, набирающих активность с конца XX столетия на постсоветском пространстве и в странах Восточной Европы, стало характерной тенденцией и отличительной чертой именно нашего времени. В чем же заключается привлекательность таких концертно-зрелищных мероприятий, которые по объективным оценкам собирают огромные залы публики вне зависимости от вероисповедания и национальной принадлежности? Для начала необходимо внести некую определенность в терминологический аппарат, отметив, что в статье речь будет идти о певческой практике православной традиции в самом широком смысле. Церковное пение, как известно, делится на две категории. Первая включает в себя богослужебное пение, исполняемое на литургии в храме, поэтому оно может именоваться литургическим или храмовым. Второе, в соответствии с Типиконом, не может исполняться во время литургии, поэтому оно является небогослужебным, внехрамовым или паралитургическим. По своей сути вся музыка является духовной, так как создается Духом, однако не всякое духовное сочинение может быть церковным, скорее, это явление можно обозначить, как религиозно-христианское сочинение.

Православная церковь, будучи долгие годы гонимой и преследуемой, сумела не только сохранить богослужебные песнопения, как часть практического богословия, но и преумножила их во много раз. Сегодня мы восхищаемся не только песнопениями знаменитых композиторов, но также открываем для себя неизвестных или малоизвестных музыкальных авторов прошлого. В чем же секрет и феномен данного явления, когда, казалось бы, творческая самореализация в данном направлении была, мягко говоря, не только малопрестижной и не поощряемой, но, порой, весьма небезопасной?

Чтобы ответить на все эти вопросы, необходимо обратиться к церковной истории. Принятие Креще- 
ния на Руси принесло с собой целую богословскую систему, певческая практическая часть которой была заимствована из византийской культуры, позже включившей в себя этнические певческие традиции, основанные на киево-печерской монастырской литургической певческой практике. На основе византийской системы осмогласия формируется самобытный знаменный распев. К XVII столетию православная певческая традиция начинает расширяться: в дополнение к строгой и аскетической монодии приходит партесный или западный стиль, характеризовавшийся многоголосием. Именно в период создания авторских песнопений цкрковно-певческий репертуар пополняется внехрамовыми или паралитургическими сочинениями, русскими духовными концертами, которые начинают проникать в храм. Итогом этому явился указ священного Синода Русской Православной Церкви от 8 июня 1797 года, запрещавший исполнять в церквях сочинения такого рода, вместо которых рекомендовалось петь псалом или канон. (Levashev, 1994, s. 10). И все же, несмотря на присущее для русской церкви стремление сохранить художественные каноны средневекового православия, это не могло сдерживать бурный процесс композиторского творчества, особенно в XIX столетии, в период доминирующего положения светской музыки. Именно в это время возникают споры, размышления и дискуссии о церковности и нецерковности авторских композиций на литургические тексты, а также их соответствии духу и строю православного практического богословия (Baluyeva, 2012, s. 159). Все это вынуждало дать ответы на ряд вопросов о том, чем же является церковное пение и к какой категории оно относится в большей мере - к православному практическому богословию или к музыкальному искусству?

Проблема церковных песнопений и их изучений не нова, на это пристальное внимание обратили первые исследователи-медиевисты в России еще в XIX веке, разделившись в своем видении истории древних песнопений на два направления. Первые, среди которых были В.Стасов, Д.Разумовский, А.Преображенский считали певческое искусство Православной Церкви формой богослужения. Другие же, С.Смоленский, протоиерей В.Металлов, протоиерей Д.Аллеманов, А.Никольский, Д.Кастальский, понимали его исключительно как явление и феномен музыкального искусства. Каков же был взгляд на этот вопрос ранее? Обратимся к высказываниям святых отцов о роли, значении, предназначении и характере богослужебного пения. Святитель Василий Великий в IV веке говорил о воздействии Святого Духа через сладкопение на нерадивого человека, «<... чтобы вместе с усладительным и благозвучным для слуха принимали мы неприметным образом то, что есть полезного в слове» (Baluyeva, 2012, s. 159). Аналогичные рассуждения можно встретить у Блаженного Августина, считавшего пение в церкви очень полезным, в особенности, когда чистым голосом поются соответствующие тексты (Baluyeva, 2012, s. 159). Святитель Иоанн Златоуст призывал петь во время богослужения со страхом и благоговейным трепетом. Климент Александрийский (III в.), рассуждая о характере и музыкальном оформлении духовных песнопений, предупреждал о воздержании от надламливающей душу чрезмерной музыки (Baluyeva, 2012, s. 160). Таким образом, святоотеческие взгляды на церковное песнопение были весьма и весьма определенными: богослужебное пение строго подчиняется Уставу, принципу осмогласия, а также служит слову, из чего можно вывести трисоставную формулу богослужебного пения: СЛОВО, БОГОСЛУЖЕБНЫЙ ПОРЯДОК, МУЗЫКАЛЬНЫЙ ЭЛЕМЕНТ (Baluyeva, 2012, s. 159). Историческая смена монодии на партесное авторское многоголосие, тем не менее, не поменяла литургической функции церковного песнопения. По мнению протоиерея А.Шмемана «литургическое понимание богослужебного пения не отменяет его принадлежности к музыкальному искусству, но предполагает его зависимость, подчинение музыкально-эстетических законов требованиям Устава» (Baluyeva, 2012, s. 162). Еще дальше в этом направлении идет Н.В.Лосский, утверждая, что «всякая форма искусства во время богослужения участвует в проповеди $<\ldots>$, проповедь есть по преимуществу богословие» (Baluyeva, 2012, s. 163). А отсутствие подчинения музыкально-эстетических норм требованиям Типикона приводит к конфликту формы (в данном случае в ее роли выступает музыкальное оформление) и содержания (тексты песнопений), и порой форма начинает доминировать, претендуя самой быть содержанием. Это в полной мере можно отнести как к опыту сочинений церковных песнопений, так и к их исполнению.

Приняв к сведению запрет на исполнение в храмах во время богослужений в XVIII столетии духовных концертов, регенты церковных коллективов организовали мощное движение за духовно-хоровые концерты, чему в немалой степени способствовала распространение и широкое признание в социуме хорового искусства, расцвет которого в Российской империи пришелся на XIX столетие. И именно расцвет хорового искусства и светской музыки при ее доминирующем положении стимулировал композиторское творчество в церковном песнопении. Новые поколения певчих, регентов уже не могли удовлетворяться предшествующими достижениями в области литургического и церковного песнопения. Поиск форм самовыражения вылился, прежде всего, в массовые концерты духовной и церковной музыки, и, несмотря на многочисленные постановления Синода РПЦ запрещающего и ограничительного характера в этой сфере, к концу века закрепились устойчивые обычаи и традиции проведения таких мероприятий во внебогослужебное время в храмах, в залах дворянских, благородных, купеческих собраний, гимназий, театров. Часто такие выступления предварялись просветительскими лекциями на тему церковной музыки. В этом смысле очень показательны концерты коллективов, проводившиеся в последней четверти XIX века в Гродно и небольших городах и местечках губернии под управлением таким мастеров, как А.Архангельский, Д.Агре- 
нев-Славянский ${ }^{1}$, П.Гордовский ${ }^{2}$, А.Карагеоргиевич, Н. Буйлов ${ }^{3}$, а также многочисленных хоров гимназистов и солдат воинских частей. Количество вечеров духовной хоровой музыки в Северо-Западном крае постоянно увеличивалось. В московской столичной прессе за период с 1895 по 1917 годы сохранились сведения о духовно-хоровых концертах не только в губернских центрах, но также в таких городках, как Замостье, Калиш, Люблин, Сувалки, Бельск-Подлясский (Польша), Лида, Волковыск, Слоним, Свислочь, Каменец (Беларусь) (Levashev, 1994, s. 20). Непосредственно после октябрьского переворота Православная Церковь переживала особый подъем, связанный в том числе и с восстановлением Патриаршества, устраивались различные духовные благотворительные концерты, к участию в которых привлекались лучшие артистические силы столицы: О.Книппер-Чехова, А.Нежданова, Ф.Шаляпин, протодиакон К.Розов, лучшие церковные хоры храмов Москвы. (Gubonin, 2015, s. 576-577). Выступления проходили при переполненных соборах и залах, часто на них присутствовал сам Святейший Патриарх Тихон. Аналогичные мероприятия стали организовываться во многих храмах РПЦ, а собранные средства направлялись в Фонд духовного образования. Святейший Патриарх Тихон поощрял инициативу проведения таких мероприятий, «<..> усматривая в них один из очень действенных путей для религиозного, богословского и церковно-эстетического воздействия на души человеческие <..>» (Gubonin, 2015 , s. 577-578). К сожалению, богоборческие власти очень быстро пресекли деятельность церкви в этом направлении на долгие-долгие годы, подвергнув многих священно- и церковнослужителей массовым репрессиям. В 50-е и 60-е годы ХХ столетия идеологический аппарат воинствующего атеизма, понимая, что замечательные, признанные во всем мире партесные хоровые концерты, например, Д.Бортнянского невозможно вычеркнуть из списка мирового музыкального наследия, совершает кощунственный подлог, издавая концерты композитора, изъяв тексты псалмов Давида и поменяв их на тексты поэтов-песенников советского государства. Так, знаменитый концерт № 32 на слова 38 псалма Давида превратился в хоровой концерт под названием «Медитация»! После распада СССР потребность в духовной, церковной, литургической музыке настолько была сильна, что, практически, каждый хоровой коллектив в

\footnotetext{
Агренев-Славянский Дмитрий Александрович (1836-1908) - русский певец (тенор), хоровой дирижер, собиратель народных песен. Пению обучался в Петербурге, совершенствовался в Италии и Париже. В 1868 г. создал хор «Славянская капелла».

2 Гордо́вский Петр Николаевич (1854 - 1898), регент, певец. Окончил Киевскую духовную семинарию, служил регентом в Петербурге. 3 Буйлов Нил Сергеевич (2-я пол. XIX-1-я треть XX в.), регент, учитель пения, духовный композитор. Имел аттестат регента 1-го разряда от Придворной певческой капеллы. В 1893 - 1900 гг. состоял помощником регента Исаакиевского собора Санкт-Петербурга. Во 2-й половине 1900-х гг. преподавал пение в Виленской женской губернской гимназии, преподавал на регентских курсах, организовывавшихся периодически в Вильно для учителей народных училищ. В июне 1908 г. принял участие в работе 1-го Всероссийского съезда регентов церковных хоров и деятелей по церковному пению в Москве.
}

своем выступлении исполнял церковные песнопения, причем, как правило, без малейшего понимания смысла исполняемого произведения. Многолетняя практика отлучения народа от практической певческой культуры Православной церкви, запрет публикации ранее созданных авторских сочинений, ограниченный доступ к богослужебной литературе, Уставу, все это вылилось в наплыв огромного количества музыкантов, пришедших просто петь в церковь, восхищаясь эстетической красотой ранее неизвестных и недоступных песнопений. Певческая практика каждого храма стала в определенный момент представлять из себя эклектическую театральную сцену. На фоне таких действий мало кто из дирижеров светских коллективов или регентов хоров (которые тоже, надо заметить, были новыми людьми в храме) понимали необходимость серьезного изучения практического богословия, Устава, Богослужебных указаний. Тем значительнее и ярче на таком фоне выглядит подвижническая деятельность редких дирижеров и руководимых ими коллективов, в частности, Гродненского камерного хора церковной музыки «Дойлідства» ${ }^{4}$. В данном случае профессиональные музыканты, заинтересовавшись песнопениями Православной церкви, организовали коллектив, который получал навыки певческой церковной практики в качестве певчих разных храмов Гродно, постоянно выступая на светских сценах в целях знакомства непосвященного слушателя с самыми различными песнопениями - как литургическими, храмовыми, так и нелитургическими. Деятельность такого рода была взаимополезной как для храмов, в которых участвовали певчие, так и для их личностного духовного роста.

Если практика духовных и церковных концертов, выступлений хоровых коллективов в церкви и за ее пределами (театральные и концертные сцены) насчитывает более 150 лет, то фестивали - явление последних десятилетий XX столетия. Одно из первых событий такого рода появилось в Польше, в городе Гайнувке (Hajnówka) в 1980 году. Фестиваль, ставший визитной карточкой польского православия, стимулировал аналогичные явления в Беларуси, где в 1989 году состоялся Минский международный фестиваль православных песнопений. Позже аналогичные форумы были организованы как в Беларуси (один из самых известных и действующих сегодня - это ежегодный Международный фестиваль православных песнопений «Коложский Благовест» в Гродно), так и в Украине, России, Эстонии, Болгарии, Литве, Сербии, Греции. При всей схожести этих мероприятий в названии и содержании, они различались и различаются как в своих целях и задачах, так и во взаимодействии с социумом. В Гайнувке фестиваль изначально был организован для объединения немногочисленных православных, позже - для знакомства социума с православной культурой Польши. В странах, где Православие является доминирующим, как Россия,

\footnotetext{
4 Деятельности и истории этого коллектива посвящено было выступление автора этой статьи на XXVII Международных научных чтениях памяти Л.С.Мухаринской в Минске (Беларусь) в 2018 году.
} 
Сербия, Беларусь, Украина, фестивали задумывались для возрождения церковной певческой культуры. И все же по направленности на массы слушателей и зрителей, по характеру воздействия все проводимые такого рода мероприятия обладают общими чертами, тенденциями, среди которых можно выделить следующие сферы:

- Богословская;

- Светская;

- Культурологическая.

Фестиваль являет собой своеобразную миссионерскую работу, направленную на несение Слова, оформленного в музыкальной молитве. Церковь, долгие годы являвшаяся гонимой и преследуемой (а на территории постсоветских государств Православная Церковь по Конституции и сегодня отделена от государства), таким образом несет миру и социуму, в котором проповедует, свет ${ }^{5}$, воздействие которого усугубляется музыкально-эмоциональным воздействием на слушателя. Именно эту функцию мы условно можем обозначить как внешней богословской. С одной стороны, демонстрируя все исторические формы певческого православного наследия, сегодня Церковь идет с проповедью в социум, к каждому зрителю и слушателю фестиваля. С другой стороны, период оттепели, наступивший в странах СССР и государствах Восточной Европы в 80-х годах, позволил православному богослужебному песнопению стать доступным слушателю, вновь выйти на концертные площадки. И если концерт - это разовая культурная акция, чаще приуроченная к календарному событию, то фестиваль - это праздник. В результате обнажилась серьезная проблема - крайне низкий исполнительский певческий уровень приходских коллективов. Возникла новая задача: повышение профессиональной певческой составляющей богослужебного песнопения, что можно назвать внутренней богословской иелью и задачей. Здесь же было бы уместно говорить и об исполнении авторских сочинений перед слушателями, сочинений, написанных талантливыми композиторами, чей музыкальный гений ярко выразился в мелодии, которая может входить в этический конфликт верующих, участвующих в богослужении тем, что отвлекает их от содержания молитвы. Очень точно об этом выразилась Л.Густова, доктор искусствоведения, директор Минского Международного фестиваля православных песнопений: «Задача фестиваля создать праздник вне службы. Православная церковь нового времени, или, так называемого синодального периода, создала целостную богатую культуру, музыкальную, в частности, которая не должна кануть в Лету. Она должна звучать в концертных залах» (Gustova, 2005, s. 145). Именно поэтому мелодическая красота, художественная ценность таких сочинений может рассматриваться как выражение определенных чувств композитора, находящегося под влиянием определенного богословского текста и места этой молитвы в соответствии с Типиконом.

\footnotetext{
5 «Во свете Твоем узрим свет», - поется в Великом Славословии на Всенощном Бдении [Пс.35:10].
}

Церковь и социум всегда находились и находятся в постоянном взаимодействии: очень часто это было агрессивная политика государства по отношению к Православию, однако, на переломе XX и XXI вв. прослеживается не только лояльное отношение, но даже тесное взаимодействие и сотрудничество. Искусствоведение, как наука, воспринимает огромный пласт богослужебных песнопений в контексте мирового хорового культурного наследия, анализируя анонимные и авторские композиции. Поэтому, выход церковных песнопений на светскую концертную эстраду может быть своего рода голосом Православной Церкви вне самой церкви, ее демонстрацией того, что составляет практическое богословие, а непосвященными слушателями воспринимаемое в качестве источника эстетического наслаждения. Говоря иными словами, церковь выступает носителем культуры того огромного наследия, которое поражает воображение своим разнообразием. Светский характер воздействия песнопений тесно связан и с культурологической функцией: в данном случае публика различных слоев социума знакомится как с весьма распространенными песнопениями, исполняемыми в ходе богослужебной практики в храмах одной епархии или Поместной церкви, так и с раннехристианскими и современными сочинениями, в том числе и других Поместных церквей, несущих на себе отпечаток национальной традиции, объединяющим элементом которых являются неизменные богословские тексты.

В связи со всеми вышеперечисленными целями вполне логично встает ряд вопросов:

- Что должно являться приоритетным в песнопениях - тексты с их богословским содержание или их передача музыкальными средствами выразительности, помноженными на талант композитора в случае авторских сочинений?

- Каким образованием, богословским или специальным музыкальным должен обладать регент церковного хора?

- Каким тезаурусом должен обладать композитор, приступающий к сочинению песнопений литургического или паралитургического содержания?

- Выходя за ограду церкви остаются ли песнопения составной частью богослужения, либо они становятся самоцелью высокохудожественного уровня, которые публика может воспринимать исключительно с музыкальной точки зрения?

Итак, попробуем разобраться во всех этих вопросах. Несомненно, что богослужебное пение интегрируется в церкви в богослужение, тем самым подтверждая, что является его составной частью. Показательны в смысле приоритета в контексте вышеприведенного вопроса слова одного из старейших иерархов церкви, митрополита Филарета (Вахромеева), Почетного Патриаршего Экзарха Всея Беларуси, имеющего, среди прочего, фундаментальное музыкальное образование: «Пение - это форма подачи богослужебного текста, донесения его до сознания верующего. <..> очень полезно внимательно слушать пение богослужебно- 
го хора: причем, не только что поет хор, но и как он поет» (Gustova, Denisov, 2005. s. 3). Значит ли это, что, акцентируя внимание на богослужебных текстах, мы полностью должны игнорировать их музыкальное оформление? Нет, здесь уместно обратиться к музыкальной семиологии. Принципиальным отличием вербального и музыкального языка является как сила их воздействия, так и то, что вербальный лишь объясняет какое-либо явление, в то время как музыкальный - помогает слушателю прочувствовать эмоциональное воздействие (Kozhenkova, 2012, s. 159). И здесь ключевой фигурой становится личность регента - человека, обладающего определенным багажом знаний, фактически, формирующего эмоциональный фон и эмоциональное воздействие богослужения на молящихся. Его образование должно содержать разумный баланс между музыкальной составляющей, предполагающей глубокое знание богослужебных и церковных песнопений в исторической ретроспективе, с учетом постоянно пополняющихся сведений по этому вопросу, и богословским фундаментом, являющимся опорой и сдерживающего от эмоциональных перехлестов. Именно тандем двух образований поможет грамотно ориентироваться не только в певческом наследии прошлого, но и грамотно подходить к формированию богослужебного и концертно-конкурсно-фестивального репертуара, включая сочинения современных композиторов. В этом вопросе в контексте современности, когда одной из определяющих черт является персонифицированность, индивидуальные качества, уровень одаренности композитора, совершенно очевидно, что простое сочинительство музыки на церковные тексты без глубокого проникновения в суть вопроса и понимания того, что это является практическим богословием, без знакомства с особенностями церковнославянского языка, без знаний традиций, истории, это всего лишь создание невзрачных музыкальных опусов при полном отсутствии того, что в церкви во время богослужения ВСЕ проповедует Слово Божие, ведь по словам того же митрополита Филарета «в храме музыкальный элемент участвует в оформлении любого вида богослужения и каждой его детали, кроме проповеди» (Gustova, Denisov, 2005. s. 3). Что же касается того, как трактовать церковные песнопения вне храма, на концертной площадке или фестивальной сцене, то тут анализ этого вопроса носит скорее социологическую окраску: верующий человек вне зависимости от того, где он слышит песнопения, всегда их отождествляет с богословской сферой, окрашенной эмоциональными музыкальными тонами, умноженными талантом композитора и переносящими его в определенный момент богослужения. Выходя за ограду церкви песнопения не перестают быть частью практического богословия, но вне храма их эмоциональное воздействие на слушателя, порой невоцерковленного, может иметь большее воздействие. Поэтому православная певческая практика, реализовываемая в организации концертов, а в особенности фестивалей церковных песнопений, являясь отражением практического богословия, проявляет себя, с точки зрения искусствоведения не только как элемент искусства, но и как компонент общественной жизни, поэтому фестивальное явление можно рассматривать как культурологический и социальный феномен.

\section{Библиография}

Levashev, Ye. (1994). Traditsionnyye zhanry Pravoslavnogo pevcheskogo iskusstva $\mathrm{v}$ tvorchestve russkikh kompozitorov ot Glinki do Rakhmaninova 1825 - 1917. Moskva: Nezavisimyy Izdatelskiy Tsentr TekhnoInfo [Левашев, Е. (1994). Традиционные жанры Православного певческого искусства в творчестве русских композиторов от Глинки до Рахманинова 1825 - 1917. Москва: Независимый Издательский Центр ТехноИнфо].

Baluyeva, N. (2012). Regent: sud'ba I sluzheniye. Protoiyerey Mikhail Fortunato. Moskva: Yazyki slavyanskoy kul'tury [Балуева, Н. (2012). Регент: судьба и служение. Протоиерей Михаил Фортунато. Москва: Языки славянской культуры].

Gubonin, M. (2015). Russkaya dukhovnaya muzyka v dokumentakh i materialakh. T. IX. Russkoye pravoslavnoye tserkovnoye peniye v XX veke: Sovetskiy period. Kn. 1: $1920-$ 1930-ye gody. Ch. 1. Moskva: Yazyki slavyanskoy kul'tury [Губонин, М. (2015). Русская духовная музыка в документах и материалах. T.ІХ. Русское православное иерковное пение в ХХ веке: Советский период. Кн. 1: 1920 - 1930-е годы. Ч.1. Москва: Языки славянской культуры].

Gustova, L. (2005). Prazdnik pravoslavnogo iskusstva. Muzykal'naya academia. № 2. 2005. S. 142 - 146. Moskva: Izdatel'stvo "Kompozitor" [Густова, Л. (2005). Праздник православного искусства. Музыкальная академия. № 2. 2005. С. 142 - 146. Москва: Издательство «Композитор»]. Gustova, L., Denisov, N. (2005). Mitropolit Filaret: Budu pet' Bogu moyemu, dokole yesm'. Muzykal'naya academia. № 1. 2005. S. 1 - 5. Moskva: Izdatel'stvo "Kompozitor" [Густова, Л., Денисов, Н. (2005). Митрополит Филарет: Буду петь Богу моему, доколе есмь. Музыкальная академия. №1. 2005. С. 1 - 5. Москва: Издательство «Композитор»].

Kozhenkova, A. (2012). Znakovaya priroda muzyki. Molodoy uchenyy. №1(36)/2012 T. II. S. 159 - 162. Chita: Izdatel'stvo Molodoy uchenyу [Коженкова, А. (2012). Знаковая природа музыки. Молодой ученый. №1(36)/2012 Т. II. С. 159 - 162. Чита: Издательство Молодой ученый]. 
ISSN 1508-7719

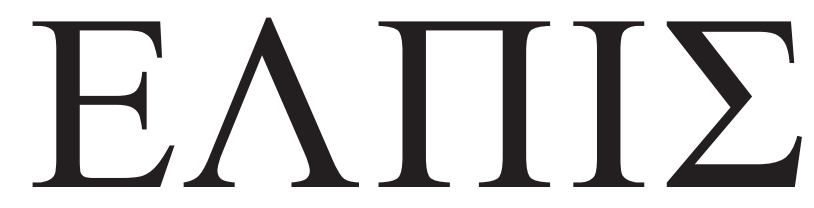

CZASOPISMO TEOLOGICZNE KATEDRY TEOLOGII PRAWOSŁAWNEJ UNIWERSYTETU W BIAŁYMSTOKU

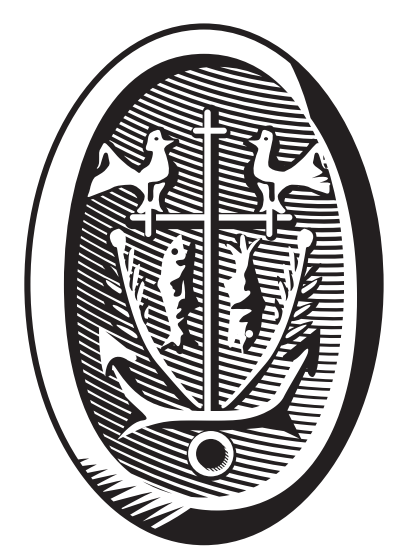

ADRES REDAKCJI

ul. Ludwika Zamenhofa 15, 15-435 Białystok, Polska tel. 85 745-77-80, e-mail: elpis@uwb.edu.pl www.elpis.uwb.edu.pl 